\title{
Vocational knowledge in motion: rethinking vocational knowledge through vocational teachers' professional development
}

\author{
Janet Hamilton Broad
}

To cite this article: Janet Hamilton Broad (2016): Vocational knowledge in motion: rethinking vocational knowledge through vocational teachers' professional development, Journal of Vocational Education \& Training, DOI: 10.1080/13636820.2015.1128962

To link to this article: http://dx.doi.org/10.1080/13636820.2015.1128962

曲 Published online: 19 Jan 2016.

Submit your article to this journal $₫$

a)

View related articles

View Crossmark data $\nearrow$ 


\title{
Vocational knowledge in motion: rethinking vocational knowledge through vocational teachers' professional development
}

\author{
Janet Hamilton Broad \\ UCL Institute of Education, University College London, Lifelong and Comparative Education, London, UK
}

\begin{abstract}
The paper presents empirical data to consider some of the current debates concerning the nature of vocational knowledge taught in Further Education colleges to students following craft, vocational and occupational courses. The concept of 'knowledge in motion' and workplace learning theories are employed as a conceptual framework to examine the continuing professional development (CPD) activities of vocational teachers. This is used to shed light on the ways in which teachers use CPD as a means of accessing and transporting vocational knowledge from occupations to classrooms. Empirical data were gathered through questionnaire, in-depth interviews and participant observation. The findings are presented around five themes: (1) the range of CPD engaged with by vocational teachers; (2) the limitations of propositional, explicit knowledge; (3) engaging with and capturing tacit knowledge; (4) managing the temporality of vocational knowledge; and (5) networking within and to the occupation. Findings suggests that vocational knowledge is distributed and networked and this conceptualisation makes visible some of the ways teachers are able, through CPD activity, to transport vocational knowledge from occupations to classrooms.
\end{abstract}

\section{ARTICLE HISTORY}

Received 19 August 2015

Accepted 29 November 2015

\section{KEYWORDS}

Further education; vocational education and training; actor-network theory; CPD; professional learning

\section{Introduction}

This paper uses Nespor's (1994) conceptual framework of knowledge in motion and concepts drawn from workplace learning theory to report on the continuing professional development (CPD) experiences of vocational teachers. It explores how further education (FE) vocational teachers, situated in contexts removed from their original occupation or industry, are able to maintain, refresh and update their vocational, occupational knowledge and utilise it to provide a more effective and relevant learning experience for students. This is used to consider some of the current debates concerning the nature of vocational knowledge taught in FE colleges to students following craft, vocational and occupational routes of study. The exploratory ideas presented here were stimulated by recent policy initiatives in England that have focused on vocational teaching and learning (CAVTL 2013) and the CPD of FE teachers 
(see, inter alia, Lingfield 2012; Statutory Instrument 2012; ETF 2014). These initiatives have added to the continuing debates and concerns over the quality, nature and purpose of Vocational Education and Training (VET) in England. In relation to curricula issues, Hordern (2014) suggests that the reorientation of VET over the last 30 years towards skills and competency outcomes has emptied out the knowledge content from vocational programmes of study. Bathmaker (2013) argues a similar point, that VET in England has been reduced to the acquisition of skill. Succinctly, Unwin $(2004,176)$ states that the UK has reduced 'its once well-respected vocational qualifications to a thin gruel of competence-based checklists'. Of equal concern is that the perceived purpose of vocational qualifications falls into three groupings (Bathmaker 2013) of: (a) developing workplace practice knowledge and skills; (b) developing generic and transferable skills, such as employability and personal learning skills; and (c) developing subject knowledge and theory. In Bathmaker's study of stakeholders from awarding bodies, who develop vocational qualifications, and government departments who set policy for vocational curricula, she found that there was a keener focus on employability skills, rather than on specialist vocational knowledge. These conflicting ideas concerning the types of knowledge that ought to be included in vocational curricula highlight some of the contentions over definitions of vocational knowledge. Young (2008), through the use of a social realist conceptual framework, attempts to deal with some of the issues of defining vocational knowledge. He uses Durkheim's distinction between the sacred and profane and Bernstein's between horizontal and vertical forms of knowledge. Similarly, in exploring vocational knowledge, Wheelahan (2007) uses a Bernsteinian analysis of 'powerful knowledge' whereby the division between vertical and horizontal discourses of knowledge is used to explore the social conditions under which knowledge is produced. In particular, Young's analysis is helpful as he raises the notion of connecting off-and on-the-job knowledge and argues that it is the nature of connections between the codified knowledge of college-based curricula and the tacit and often uncodifiable knowledge of the workplace that is the basis for what is distinctive about vocational knowledge. However, both Durkheim and Bernstein, on which Young draws, envisage knowledge as a dichotomy of sacred and profane, and vertical and horizontal. These either/or approaches render them problematic for use in examining how teachers through their CPD link classrooms to workplaces, connect off-and on-the-job knowledge and transport the tacit into classrooms.

A similar dichotomy can be seen in the positioning of vocational against academic knowledge and has bedevilled VET and clouded debates concerning vocational knowledge. Bathmaker $(2013,89)$ suggests that vocational education is '... regularly positioned as a second chance, and often second choice, alternative to general subject based "academic education"'. She found that a second imperative for awarding bodies and policy-makers when designing and planning VET curricula and policy was of ensuring equivalence with academic General Certificate in Secondary Education (GCSE) and A level qualifications. Avis et al. (2012) also argue that VET in the UK has historically been accorded lower status than academic general education. In response to this, successive governments have made torturous attempts to engender parity of esteem between vocational and academic qualifications with little success (inter alia, Unwin 2004; Butcher 2003; Keep and James 2011; Wolf 2011). This vocational vs. academic knowledge dichotomy can be traced back to mediaeval universities where the distinction was made between liberal and practically useful knowledge. Muller (2009) describes this as a fault line that is still in evidence today, whereby only the seven 
liberal arts were taught in universities and not the seven mechanical arts of cloth-making, shipbuilding, navigation, agriculture, hunting, healing and acting.

In order to challenge dichotomous and parity assumptions and to offer an alternative approach in understanding vocational knowledge, two theoretical lenses are employed in this paper to understand both how teachers can capture vocational knowledge and how CPD experiences can be utilised to facilitate the transportation of vocational knowledge to formal classroom settings in English FE colleges. Firstly, workplace learning theory (see for example, Eraut 2004; Allix 2011) makes distinctions between academic and vocational knowledge. Within workplace approaches are debates which argue that vocational knowledge is on the whole tacit, non-formal and largely uncodified (see, inter alia, Polanyi 1967; Eraut 2000; Hordern 2014). Within this, Guile (2010) offers a view that gives tacit knowledge primacy and recognises that individuals learn different types of knowledge in different ways. This raises a particular issue in that if vocational knowledge is tacit and therefore problematic to codify, how is it transported across contexts. This in turn highlights how for both curricula designers and vocational teachers, both the identification of vocational knowledge and its reduction into transportable forms such as text books, used for the more general academic knowledge of GCSEs and A levels is problematic. Thus, a second conceptual lens is used to flesh out the transportation processes. Using Nespor's (1994) concept of knowledge in motion, it is argued here that vocational knowledge moves across contexts through networks and it is the actions of vocational teachers through their CPD that enables this process.

The remainder of this paper is divided into four sections. The first fleshes out the theoretical framing more fully, the second briefly details the methodology used in the study. The third presents the findings followed by the fourth, a discussion of findings and concluding remarks.

\section{Theoretical framing}

Tacit vocational knowledge is often contrasted to codified propositional knowledge and Guile $(2011,454)$ differentiates between the situated and tacit as 'know how' and decontextualised and codified as 'know that'. However, an issue within this binary is that as Polanyi (1967) recognised, the boundary between the two is not clearly definable and knowledge does not easily slip into one or other of these categories. Polanyi suggests that all knowledge is a permutation of both tacit, un-codified and, explicit, codified knowledge and that knowing is the action of integrating the two. A further way in which this slipperiness is demonstrated is as Hildreth and Kimble (2002) suggest, that it is possible to make certain aspects of tacit knowledge explicit and to encode it. An analysis of this leads to the conclusion that there are three distinct possibilities of codification, that which can be relatively easily codified, that which cannot be codified as it is inaccessible and, between these, semi-codified knowledge, which is possible but problematic to codify.

Codified knowledge, is defined here as that which is that found in the curriculum offer, in courses, assessment and accompanying text books and other teaching and learning materials (Guile 2011). However, workplace practices, customs, approaches, new ideas and ways of doing, which also need to be reflected in vocational curricula are defined by their resistance to codification. Nevertheless, practices of the codification of vocational knowledge are often treated as unproblematic and are illustrated by Gamble (2006), who suggests that codified knowledge in printed pattern books and plans have enabled, within post-industrial workplaces, a separation of thinking from execution. Gamble's critique of the separation of 
thinking and doing highlights the assumption that work practices and vocational knowledge can be codified and transported to classrooms via artefacts unproblematically and simply, and by third parties removed from the direct process of teaching and learning.

This raises a problem as tacit or uncodified knowledge makes up the significant majority of knowledge shared, used and applied in vocational settings. It is developed through practice (Hordern 2014). Contrasting codified and tacit knowledge, Polanyi (1967) described tacit knowledge as that which we know but cannot tell. Livingstone and Guile (2012) argue that tacit knowledge, because it resists codification is becoming the most important form of knowledge in learning organisations and that increasingly for the production of new knowledge, it has become more strategic to attempt to capture informal knowledge generated in informal ways. It is therefore difficult to visualise how vocational knowledge is transported for use in FE classrooms.

Between the two lays knowledge that is in part codified. The purpose of this level of codification is to enable the sharing of knowledge within a particular occupation or industry. Unlike codified knowledge found in classrooms, the artefacts, processes and mechanisms utilised to capture work practice knowledge are not produced or organised specifically for formal curricula purposes, but for use by those within the occupation or industry. It is similar to product knowledge described by Fuller et al. (2003), where they describe how information for new cars is codified in manuals and brochures held in the sales manager's office and online for use with sales executives and customers. Zollo and Winter (2002) in their study of Japanese corporations conceptualise semi-codified knowledge as that shared between 'insiders'. They describe this centrally positioned form of knowledge as diffused, fuzzy and semi-codified and define it as institutionally based knowledge that is provided only to trustworthy insiders. In terms of the tacit vocational knowledge that needs to be captured for transportation to classrooms, this could alternatively be viewed as trade secrets that are most easily accessed by insiders or vocational experts.

Polanyi's original conceptualisation of tacit knowledge is also helpful in examining where knowledge is said to reside. One interpretation views tacit knowledge as personal knowledge that resides within the individual whereas the alternative interpretation sees it as a part of a community of practice. Both Canning (2008) and Kotzee (2012) maintain that Polanyi, in his development of the concept of tacit knowledge and Schön (1991), in his use of tacit knowledge in understanding reflective practice, see tacit knowledge as residing within the individual. Eraut (2000) also takes this line and discusses tacit knowledge in terms of personal knowledge. However, alternate applications, view tacit knowledge as a shared endeavour. Fox (2000) highlights the problem of viewing tacit knowledge as residing in individuals and by drawing on Lave and Wenger (1991), suggests that it should be seen as part of a community of practice. McArdle and Ackland (2007) in their study of how communities of practice develop outside of a formal CPD programme for adult and community teachers, also see tacit knowledge as residing within communities of practice, rather than the individual. Important in these two studies is that they highlight how knowledge can be understood to be shared both within practice and at times seen to cross-organisational boundaries and contexts.

These epistemological discussions concerning the nature of vocational knowledge, whilst further understanding, do not offer much in the way of explanations of the ways in which vocational knowledge can be transported from occupation to classrooms. By utilising the concept of knowledge in motion and by viewing its development and distribution as a network effect, it begins to shed light on the processes involved. Nespor (1994) in his empirical 
study of physics and management students on undergraduate programmes examines knowledge as a relational network. He views learning and knowing as emerging through materialising networks and network practices (Fenwick and Edwards 2013). He firmly moves his argument away from both individualistic approaches and being bounded by contexts. He examines students' experiences and development through theoretical exploration of space, time and curriculum and uses this to demonstrate how activities are organised across space and time and how space and time are produced in social practices. This space-time concept can be understood through an example he gives of how physics students, situated in different parts of the USA, engage in social relations with one another through a standardised curriculum of tests and text books. Harvey (1989) explains this time-space compression as the articulation of global processes in local settings, whereby students can be brought into contact with others in different times and settings. Through this, knowledge can be seen as a network effect that organises space-time so that we can simultaneously interact with people and artefacts in our immediate environ and with those spatially and temporally distant. A point to note, however, is that unlike workplace learning theory that views knowledge as tacit and situated, Nespor sees knowledge as organised into disciplines. Nevertheless, network analysis is equally applicable to considerations of vocational knowledge. Through studying network structures and multiplicity, how knowledge practices move across contexts and boundaries can be examined (Fenwick, Nerland, and Jensen 2012) and enables an examination of how teachers transport vocational knowledge.

A significant attribute of vocational, practice base knowledge is that it has high levels of currency. Gruber, Mande, and Oberholzner $(2008,114)$ who, on discussing the professional development needs of vocational teachers state, $\ldots$... practitioners with substantial work experience can see the currency of this knowledge erode in rapidly changing technologies and operating systems. As work practises and new trends develop, it soon ensures that even high levels of vocational knowledge can become obsolete and outdated quickly. In addition, Avis (2012) suggests that VET is not all of a piece. It is subjected to a range of understandings and is marked by temporal shifts. He adds that workforces transcend temporal and spatial constraints. This second point is also highlighted by Bound (2011), who, in discussing the professional development needs of Australian vocational teachers, suggests that in part, the temporal factors of the workplace can provide both opportunities or barriers for learning. Similarly, CAVTL (2013) in their review of adult vocational education teaching and learning, argue that vocational learners, who find themselves in the classrooms of vocational teachers, are distributed through occupations at different workplaces and thus reflects changing spatial and temporal patterns of work. Network theories also use this concept of temporality and Nespor's study enables a theoretical linking of teaching to disciplines through spatialised and temporalised practices (Malcolm and Zukas 2009).

Through these we can see that currency and temporality ensure that knowledge is fluid and in flux. This then reinforces a conceptualisation of knowledge as part of a network that is always in motion. 'If a dancer stops dancing, the dance is finished'. (Latour 2007, 37). Latour further explains this as if a planned festival did not go ahead or a newspaper was not printed today then the grouping would be lost. The festival or newspaper is not solely a building or site, or some other concrete artefact, or a particular context, but an assemblage of things that need movement, circulation and connections to ensure its continuation. The importance of these concepts and in particular, the connectedness, is explained by Nespor $(1994,11)$ : 
People need labs, notebooks, computers, equations, and colleagues to be 'physicists'; suits, offices, memoranda and organizations to be 'mangers' (and the whole pathway that leads people into configurations with these elements is the key here, not just possession of them). Drop a student of physics or a manager on a deserted island without their tools and colleagues and the questions of what they 'know' and in what sense they've learned are rendered moot.

This highlights where workplace theories and the work of Nespor are complementary, however, where workplace learning theory views knowledge as residing in the materially bounded contexts of specific workplaces, shared within communities, network theory views it as residing in fluid and ephemeral networks of both people and inanimate things not always bounded by context. Thus, vocational knowledge cannot be analysed as a separate entity, but must be examined as it works and networks with other parts of the network, for example, where teachers and industrial experts come together. It must also include the human and non-human entities within the network (Fenwick, Nerland, and Jensen 2012). Alongside individuals and groups, it must acknowledge the tools and artefacts, and the contexts and places where vocational knowledge is shared and disseminated.

This brings us to the final important conceptual tool for examining vocational knowledge, the mechanisms used to transport vocational knowledge across contexts. As Latour (2007, 174), reminds us, '... to be transported from one site to the next you now clearly need a conduit and a vehicle'. These vehicles can be conceptualised as inscription devices. These are a distinct form of entity within network theory, conceptualised as artefacts that carry meaning. The concept of inscription devices was developed by Latour $(1987,68)$ whose initial definition was, '... a visual display of any sort of scientific text ..... For him, it is a semiotic representation of laboratory work, the effort and resources mobilised to make scientific facts and serves as a junction between two worlds by presenting to one a visual representation of the other. In an example given by Latour (1987), a particular laboratory instrument, a physiograph, produces a raw image, a representation of some scientific findings. This raw image has been enacted into being within the laboratory. It then becomes a figure within a scientific journal and through this journey it has become an inscription device, a shorthand diagrammatic account of laboratory work. The importance here is that it can now connect to other worlds and spaces. It has become a looking glass, enabling the reader of a scientific journal to see into the laboratory.

From this early usage, the concept of inscription devices, through its use in a variety of contexts has widened. For Munro (2009), it can take other forms and begins with the invention of writing. From this invention, a sealed letter of instructions can be sent far and wide, thus mobilising at a distance. The distinctive feature of inscription devices however, is that they are miniaturised and mobile representations of one world within another alternate world. Mützel (2009), believes they serve a specific purpose in that through them, actor-networks can become durable. This occurs through the way in which practice is transformed into material entities. In other words, the ethereal here and now is turned into a permanent artefact that records it ad infinitum, although the meanings attached to these remain fluid and open to interpretation. These artefacts are able to represent tacit vocational knowledge but cannot fully solidify and make concrete. More recently, Ceulemans, Simons, and Struyf $(2012,39)$ have classified teacher professional standards as inscription devices. Within this work they have again widened their reach and view them as, ${ }^{\prime} \ldots$ all types of transformations through which an entity becomes materialised into a sign, an archive, a document, a piece of paper, a trace'. 


\section{Methodology}

The study which took place in 2011 and 2012 captured and analysed quantitative and qualitative data from teachers working in the FE sector who had studied for a PGCE for the education and training sector in two universities in the previous five years. The initial quantitative data were captured through an electronic questionnaire and was completed by 88 teachers. The nature of the PGCE programmes is that they attract in-service students from a wide range and number of colleges. Those who responded were employed by 33 different colleges in England. The range of subjects and occupational areas the teachers taught was varied with 29 different subject and occupational areas identified. From the teachers' responses to the initial questionnaire, 57 teachers were identified as vocational teachers. The occupational areas covered included non-advanced vocational occupational areas such as hairdressing, motor vehicle and construction, through to equine and land studies, sports and physiology, dentistry and information technology to advanced vocational occupational areas such as social work, youth work, human resource management, applied sciences and social care. A further 11 were identified as probably being vocational teachers who taught other subjects to the same vocational students such as biology at an agricultural and equine college, or key skills to vocational students. The questionnaire was followed up with in-depth interviews with seven vocational teachers, purposively sampled from the 57 identified vocational teachers in order to explore a range of occupational areas taught in FE. The occupational areas chosen for interview were early childhood education, applied sciences, construction, students with learning disabilities following vocational programmes of study, human resources (HR)/ business administration, hairdressing and graphic design. This enabled emerging themes to be explored and for vocational teachers to discuss their CPD experiences. A key finding from the interviews was that professional associations offered teachers rich opportunities for the development of occupational expertise and informed the design of the third and final stage of the study. This particular aspect of the study employed a research approach first introduced by Latour (1987) of 'following the actor' and used participant observation and further in-depth interviews to follow the activities of the Association of Hairdressers and Therapists (AHT). This professional association was used as the research site as it was reported on by respondents at the interview stage as being an active and established community. It is also an association specifically for teachers of an occupational area and it afforded vocational teachers opportunities to network with industrial experts and practitioners. In-depth interviews were conducted with teachers of hairdressing: hairdressing teacher $A$ at a competition organised with a hair products company at a North London College; hairdressing teacher $B$ at an professional association regional competition; hairdressing teachers $C$ and $D$ at a professional association conference and; hairdressing teacher $E$, the chair of one of the professional association regions. Whilst not representative of all vocational teachers in FE, the findings enable insights into the nature and purpose of CPD for developing occupational expertise and knowledge.

\section{Findings: examining and understanding vocational knowledge}

The empirical data from the questionnaire, in-depth interviews and interviews undertaken at the ethnographic stage are structured in this paper around five themes: (1) the range of CPD engaged with by vocational teachers; (2) the limitations of propositional, explicit 
Table 1. What activities do you do for the purpose of subject and occupational updating?

\begin{tabular}{lcc}
\hline Reading journals and books & $81.1 \%$ & 60 \\
Accessing materials, resources or communities online & $68.9 \%$ & 51 \\
Attending a workshop & $62.2 \%$ & 46 \\
Practising in the subject specific area & $60.8 \%$ & 45 \\
Involvement with a professional body & $58.1 \%$ & 43 \\
Attending a short course & $51.4 \%$ & 38 \\
Peer observation & $51.4 \%$ & 38 \\
Accompanying students on educational trips & $32.4 \%$ & 24 \\
Organising guest speakers & $28.4 \%$ & 21 \\
Attending a long course & $18.9 \%$ & 14 \\
Shadowing someone in the subject specific profession & $13.5 \%$ & 10 \\
Industrial placement & $9.5 \%$ & 7 \\
Other (please specify) & $7.0 \%$ & 5 \\
Answered question & & 74 \\
\hline
\end{tabular}

knowledge; (3) engaging with and capturing tacit knowledge; (4) managing the temporality of vocational knowledge; and (5) networking within and to the occupation.

\section{Range of CPD engaged with by vocational teachers}

Respondents to the questionnaire were asked to indicate, against a pre-determined list of 12 common CPD activities, those they used for the purpose of maintaining subject and occupational expertise in the previous year. The findings suggest that teachers engage with multiple activities that take a range of forms (Table 1 above). Some of these are similar to those of Lloyd and Payne (2012) who, in a comparative study of hairdressing teachers in England, Wales and Norway, identified three ways in which hairdressing teachers maintain and develop their occupational expertise. These were, through working occasionally in a friend's salon, by suppliers of hairdressing products offering training opportunities, and through collaborative learning within the college by sharing ideas and reflecting on practice.

In the findings presented here, the most commonly used CPD activity was reading, carried out by 60 respondents (81\%), followed by accessing other materials online (51 respondents $/ 60 \%$ ). Many teachers engaged in workshops (46 respondents/62\%) and short courses (38 respondents $/ 51 \%$ ) and many continued to practice in the occupational area (45 respondents $(61 \%)$. Teachers also indicated that they learnt alongside their students through guest speakers (21 respondents/28\%) and educational trips (24 respondents/32\%). For many, active involvement with a professional body (43 respondents) afforded CPD opportunities. These activities and others, identified by teachers at interview, were further explored. At interview, three questions were posed to generate a discussion with respondents that centred on CPD activities carried out, which of these were viewed as having a positive effect and those found to be of no particular benefit.

\section{The limitations of propositional, explicit knowledge}

The boundary between propositional, explicit knowledge and tacit knowledge is slippery, and it is, as acknowledged by Polanyi (1967), difficult to define. Knowledge does not easily slip into one or other of these categories. Nevertheless, codified knowledge is the basis of courses, assessment accompanying text books and other teaching and learning materials (Guile 2011). It is that which forms the foundation of formal off-the-job vocational 
programmes provided in FE. Evans et al. (2010) posits that in terms of vocational education, codified knowledge is recontextualised workplace knowledge that has been simplified, recast and made more teachable and learnable. Long courses, an activity identified through the questionnaire can best be described as providing participants with a formal and assessed course, dealing with propositional, codified knowledge through a defined curriculum and assessment process. An example was offered at interview by the HR teacher of a master's degree business course he was currently enrolled on. Although 19\% (14 respondents) of teachers stated that they had been enrolled on a long course in the previous year for the purposes of occupational development, it was placed 10th out of 12 CPD activities with other approaches more commonly used. This suggests that teachers do not naturally turn to long courses when attempting to develop occupational expertise.

In a similar light, formalised and codified curricula are viewed by teachers as having limitations for their own students. In their teaching, they attempt to go beyond what is required by the formalised curricula offer and use their CPD experiences as a basis for enrichment and enhancement. The construction teacher explained at interview:

so I'm just thinking in the second year when they have all the work done [that is required by the formal curriculum], to perhaps do something different, whether it's a bit of veneer work, whether its curved work where you know, we use vacuum bags, or some steam bending [...]. But yeah, maybe introduce techniques like that, I would like to do that.

Similarly, the hairdressing teachers recognised that competitions offered experiences to students outwith and beyond that which can be offered by a codified, propositional curriculum. One AHT hairdressing teacher (C) said:

\begin{abstract}
A lot of them [the students] if they work in a salon, that's [entering competitions] the only time they will get the chance to do things that are fun, that are creative. Most of them, not all of them, most of them will just work in salons every day, do clients and that will be it. A couple of them may get the chance to do things like that again. This is the opportunity for them to do it and to me that is what hairdressing is all about, it's been creative.
\end{abstract}

This suggests that the formal curricula of vocational courses in FE, whilst necessary and beneficial in many ways, does not offer as rich an experience as teachers would wish. It perhaps chimes with the findings of Bathmaker (2013), who found that the focus of many FE vocational courses was not necessarily vocational knowledge, but more usually generic and transferable skills such as employability.

\title{
Engaging with and capturing tacit knowledge
}

CPD activities enable teachers to network with, collect and transport tacit knowledge that has already been semi-codified for other purposes. Semi-codified knowledge is that produced for, and normally used and shared within, the specialist area. The purpose of semi-codified knowledge is to enable professionals to share knowledge within the occupation or industry. It is not, as with codified knowledge, found in textbooks and curricula documentation and is not necessary produced for the consumption of students. These artefacts and mechanisms for sharing are inscription devices (Latour 1987) that provide a concrete display through text and diagrams. It can take the form of specialist materials used to share product knowledge (Fuller et al. 2003). It can also take the form of insider knowledge, provided to trusted insiders (Zollo and Winter 2002) and within occupational settings would be trade secrets, particular ways of doing, shared within the boundaries of the occupation. In this second example, 
teachers themselves act as transporters of vocational and occupational knowledge and is returned to shortly.

The most frequently used category of CPD, books and journals takes the form for vocational teachers of occupational publications produced for disseminating and sharing of specialist knowledge. These often take the form of journals and magazines provided by professional associations, an example of which was described by the applied sciences teacher. He explained how the articles and news items afforded access to up-to-date and current occupational knowledge. Of importance was that this current knowledge, reduced to an inscription device by the professional publication can be easily transported to the classroom by the teacher. The applied science teacher explained, '... this is all aimed as being a practitioner, but I can double this up for teaching ..... However, this specialist, semi-codified occupational knowledge does not always translate easily to classrooms and conversely, the $\mathrm{HR}$ teacher felt that the material in his professional body publication to be of little practical use. He said:

They would be interesting if it was affecting the course I am running but it is very bland stuff that they write about ... I think they are cutting back at the moment, it used to be a lovely, very big thing with pull-outs and things like that but it has gone very thin and not as much stuff.

Evident here is that although the material may be useful to practitioners, the HR teacher found it problematic to incorporate the material into teaching and learning. This particular publication could not act as an effective boundary object and so was not able to act as an interface (Gholamreza and Wolff 2009) between the occupation and classroom.

Other specialist occupational publications such as within the construction and the hair and beauty industry are provided on a commercial basis. Whilst the envisaged purpose of these is to enable the sharing of new vocational knowledge between practitioners, teachers are able to utilise these both for their own professional development and to enrich the teaching experiences of their students. The hairdressing and construction teachers discussed at interview how they accessed trade journals through the college library.

Much vocational knowledge, as it is developed through practice (Hordern 2014), is not available to teachers through occupational publications. In addition, it is performative (Mulcahy 2011) as it is developed through practice, with others and only existent in the here and now, it is not captured through the formal curriculum artefacts. Thus, teachers capture it through self-made inscription devices. The mechanisms teachers used was captured through the in-depth interviews and through the participant observation and interviews with the AHT professional association. The most commonly used method of codification into inscription devices is through photography. Inscription devices are defined by Fenwick and Edwards (2011) as immutable mobiles through which innovation became visible. Hairdressing teachers often capture images of new and innovative ideas from student competitions organised by the AHT. Teacher D explained:

I'll go to a competition and I'll photograph other people's work because I'm sat there at the competitions and say that colour is lovely on that ...

The way that techniques captured are transported to classrooms was also explained by the same teacher who added, '.. . and then I take it back and we use it in what we do'. Hairdressing teacher (B) explained watching a particular competition where one student was creating a specific look, using the very traditional technique of 'fingerwaving'. Even though this is a well-known hairdressing procedure, introduced in the 1920s, it requires a high level of skill. 
The student working in the competition used specialist clamps and tools to simplify the process. The teacher $(\mathrm{B})$ commented that:

I've not seen that tool used in that way before. So I've taken some photographs and I'm going to go and get that tool when I get back.

The use of photographs was also identified by the applied sciences teacher:

Oh my patients are always cropping up in my lectures. They pop up all over ... I take an awful lot of pictures ... when they have got interesting problems and bits and pieces.

The reason why cameras are used to record new vocational knowledge is because vocational knowledge is both tacit and situated within context (Fox 2000). In these examples, cameras are acting as entities within a wider actor-network (inter alia, Callon 1986; Latour 1996; Law and Hassard 1999), enabling teachers to capture and transport knowledge to other contexts. These visual representations suitable for transportation are inscription devices (Latour 1987), or visual displays, that can be used to carry new knowledge into classrooms.

However, these artefacts and inscription devices, which link across space and time, are not only visual representations, codified into concrete, tangible artefacts. They also, as with insider knowledge described by Zollo and Winter (2002), where occupational knowledge is shared between insiders, take the form of articulated discussions between teacher and students. The graphic design teacher explained how information gained at exhibitions improves professional conversations with students, 'You can just talk about this nature or that nature of the work'. and that this gives both him and his students a powerful contextual reference for the projects that students may be working on. Similarly, the applied science teacher stressed the importance of his professional development activities and that these enabled more informed discussions with his students. He said, 'And it's good to be able to turn round to students and say "when I was in practice the other day, I saw blah"...'Likewise, the construction teacher identified how conversations based on CPD experiences improved the pedagogical experiences of his students. For him, this meant sharing his experiences with students and asking such questions as, 'What do you think?'These inscription devices of resources, artefacts and discussions act as boundary objects that enable translation though the process of folding. They, '... become circulated to link local sites.' (Fenwick and Edwards $2011,716)$. They enable time and space to be compressed so that teachers and students are able to, 'move through space materially, and simultaneously move and construct space-time through practices of representation' (Nespor 1994, 131).

\section{Managing the temporality of vocational knowledge}

Leaving the discussion concerning the tacitness of nature of vocational knowledge, I now turn to presenting findings that suggest ways in which teachers mange both the temporal and currency aspects of vocational knowledge. Over a third of teachers accompany students on educational visits (Table 1 above). However, whilst important and worthy of further examination here, care should be taken over this finding as it does not differentiate between partand full-time teachers. Lloyd and Payne (2012) found in their study that part-time teachers did not enjoy the same access to CPD as their full-time colleagues and were often used to cover classes whilst full-time teachers attended CPD training. Nevertheless, where teachers did access educational visits, they were found to be valuable for both students and teachers. 
The graphic design teacher had taken students to an exhibition at the British Museum of the work of the British ceramic artist, Grayson Perry. He described the benefits as:

So because in terms of just having contemporary and topical input from gallery visits and museums that have a graphics content and a graphics significance, very much, I would think that from an FE graphic design, art and design perspective, any visit to a gallery can be useful.

He also accompanied students to the British Design Museum. He described this as being of real benefit to his subject development and said, 'That was a great thing to look at, seeing the work, as a way of seeing stuff which has a significance to the industry'. The rich experience of being able to view artefacts in their original and authentic form was contrasted to seeing design in books. He said, 'When something is in front of you as a tangible artefact, rather than in a book, it sets the scale and that's certainly useful, any visit like that is useful'. Here, the temporally described (Baiocchi, Graizbord, and Rodríguez-Muñiz 2013) pictorial representations found in design books, that would usually be used in classrooms, are stabilised into concrete artefacts. These visits work within the teaching and learning network to '... synchronise meanings, and actions across time and space and multiple actors'. Hamilton $(2011,714)$ and enable teachers and students to connect with the occupational world.

Harris-Hart (2009) describes temporality as bridges between or to the past, present and future. The importance of the historical basis of occupations and how teachers attempt, through their CPD, to move back in time, highlights the temporal historic nature of vocational knowledge. The construction teacher described his visits, without students, to the Victoria and Albert Museum. This afforded assess to historical aspects of joinery through exhibitions of furniture styles from different periods and he explained these as, 'They have got some incredible exhibitions from Arts and Crafts, Art Nouveau, all the way through'. and stated that, 'It's incredible actually'.

Reflected in the two experiences described above is that museums and exhibitions enable teachers and their students to study both current trends and historical aspects of the occupation. The importance of identifying ways of returning to the historical roots of a particular occupation was also highlighted by the graphic design teacher who explained some of the CPD activities he had been involved in concerning basic craft design:

... which is to do with the notion of basic printing, so printing from a hot metal press, printing from silkscreen and doing some of those practical, perhaps regarding as old school graphic design [...] to renew my acquaintance with it.

He continued to explain that the whilst the introduction of new technologies in the occupational area had changed work processes, the central aspects of the work, the approaches and thought process had not changed significantly, 'Often particularly with graphic design people think it all happens on computers but in fact, no it happens in the brain'. Teachers also address the high levels of currency in many occupational areas by encouraging students to enter competitions. These are organised through professional associations such as the AHT, and nationally and internationally through WorldSkills. ${ }^{1}$ The benefits were explained by a hairdressing teacher (D) who said, 'You see the changes and the styles changing and the fashions and the colour trends coming through'.

Through these examples and explanations, the temporal nature of vocational knowledge becomes visible. It does not run and develop chronologically and so teachers attempt to both revisit and appreciate traditional approaches and techniques whilst ensuring that they are familiar with advances and current trends. 


\section{Networking with and to the occupation}

Sixty-two per cent of teachers had attended a workshop and $51 \%$ a short course to develop occupational expertise (Table 1 above). At interview, teachers also discussed the importance of specialist short courses and workshops. These are often organised by manufacturers who provide materials, products and equipment for an occupational area and provided for practitioners. Examples were given by a hairdressing teacher (A). Her employing college stocks a particular manufacturer's products and in return, free courses are offered. The teacher had attended a bridal, long hair course with one manufacturer and one on hair colour provided by another manufacturer. The construction teacher described a five day non-certificated course, provided by a manufacturer of joinery equipment and tools. This course comprised of him making, from start to finish, a Windsor chair ${ }^{2}$ and afforded opportunities to learn traditional techniques in wood-making, '... it was covering techniques that I haven't had experience of myself in my woodworking career, one of them being steam bending [...]. The other part of it too, was wood-turning which I haven't done much of'.

The importance of sites where product knowledge is shared is explained through the concept of symmetry (Callon 1986; Latour 2007) and Cordella and Shaikh (2006) state reality is a heterogeneous network of relations, made up of human and non-human actors. These examples of CPD demonstrate how human action cannot be separated from the material world as both make up the reality of the network. If these courses were not provided, then a part of the wider network would be closed off and the dance would be finished (Latour 2007). An effective avenue for manufacturers to disseminate information regarding their products, and for those in industry to learn about them would be cut-off and would impact on the potential reach of the particular manufacturer.

These types of CPD can therefore seen to be symbiotic as there is benefit for both the teacher who gains new skills and for the manufacturer. For example, when asked why the week long course was provided for the construction teacher, he answered that,'It's research development for them too'. The manufacturer was able to solicit professional opinions of the tools used whilst on the course. Similarly, for the hairdressing teachers, if they are offered CPD by a particular manufacturer, they are more likely to use and subsequently recommend that particular manufacturer's tools and products to their students. This was described by the hairdressing teacher in the second stage interviews as, 'I mean it's basically them trying to sell but it was still quite good'.

\section{Discussion and concluding remarks: knowledge in motion}

This exploratory paper has discussed the nature of vocational knowledge and used the CPD experiences of teachers to explore how they, situated in classrooms removed from the occupation they teach, are able to maintain and refresh their vocational knowledge and utilise it to provide a more effective and relevant learning experience for their students.

The vocational knowledge reported on here, as accessed by teachers through their professional development, is commonly tacit in nature and is commonly un-codified or semi-codified. Due to the tacit nature of vocational knowledge, it is problematic for those separated from the direct processes to access, capture and transport across contexts. As Canning (2008, 4) explains, tacit knowledge is '... incomprehensible and integral to action. Not something that can be made explicit and the object of rational thought. [...] There is always a remainder, 
a residue that is unknowable and inexplicable'. This concept of action, that Canning alludes to, is central to understanding vocational knowledge as it infers motion.

It is evident, through the experiences reported here, that vocational knowledge is also temporal with high levels of currency. Temporality is defined by Harris-Hart (2009) as bridging between the past, present and future and can be identified by the types of knowledge that teachers seek. Teachers use CPD to connect with both historical, traditional aspects of their occupation to refresh their ideas and knowledge, and also with the latest developments. They visit museums and art galleries to connect to traditional and historical aspects, and to student competitions, workshops and short courses to connect with latest developments. The historical and occupational sites occupy other worlds than teachers, situated in FE colleges, occupy and so CPD activities are employed as bridges that link to and enable participation in the occupation. For Nespor $(1994,132)$, '.. participating means becoming spatially and temporally organised in a form that moves you into the material spaces of the field'. Through their experiences, teachers seek opportunities to engage with others. Nespor argues that these others are also part of distributed actor-networks and by examining these, the organisations and individuals that teachers come into contact with through their CPD are made visible. Powerful mechanisms that teachers use are the symbiotic relationships with manufacturers and the student competitions that offer places and opportunities for teachers to network. These networked sites are nests of activity and can best be conceptually understood as nodes within the network. Fenwick and Edwards $(2011,712)$ describe nodes as, ${ }^{\prime} .$. one thing becomes hooked to and even changed by another ... and then to another, and so on, to form an assemblage that moves'. Thus, the entities within the network, and the network, constantly perform, bringing new entities in, excluding others, redefining what they are and forging new links and nodes to other networks. Therefore, these networks forged by both the occupation and teachers are fluid and the chains of links they make, as they perform, will be diffuse and open to change. This process is made visible through the tools, equipment and products, the new entities, which form the basis of the courses provided by manufacturers and are the new techniques that students showcase in competitions.

Conversely and because of this fluidity, networks are inherently unstable as can be identified from the experiences of the HR teacher, when he found the publication provided by his professional association of little use for his practice as a teacher. Thus, the node making within networks is an essential part of making these actor-networks more secure. This is because the bridges between contexts, the nodes that connect them, which are the boundary objects between them, do not develop or circulate in isolation, or without the influences of other actors and entities with the network. The creation and management of boundaries objects requires both collaborative work and communication between the two worlds (Star 1990). These network nodes and connections reveal how vocational knowledge travels and highlights the nature of vocational knowledge as a circulation, whereby knowledge is passed and shared between the actors within the network. However, the danger is that if this constant motion ceases, the network ceases to exist. Thus, even when it appears that relationships developed through teachers' CPD activities may appear to be robust, they are in fact, '... merely fragile associations of heterogeneous elements'. Christiansen and Varnes $(2007,286)$. An example of this would be if the manufacturers described by teachers ceased to offer training through dissemination workshops and course, their products would become less known and overtaken by those of other manufacturers who do offer training and dissemination. 
This circulatory network of vocational knowledge, described so far, extends through the bridges of activity teachers construct to FE classrooms and workshops and the students who inhabit these through the use of inscription devices. According to Latour (1987) inscription devices are a visual display of something that travels the world, connecting various points across space and time. For Latour, these inscriptions are charts, tables and maps. For the teachers reported on here, they are ways of both gathering up semi-codified knowledge, and the codification of aspects of tacit knowledge into transportable forms of: (a) visual representations, captured using photographs of new techniques; (b) semi-codified knowledge in the form of catalogues and other artefacts from sites teachers visit; and (c) teachers acting as inscription devices.

Thinking about vocational knowledge in this way allows its nature to become visible in that it has, '... become circulated to link local sites' (Fenwick and Edwards 2011, 716). This is because these inscription devices enable time and space to be compressed so that teachers and students are able to, '... move through space materially, and simultaneously move and construct space-time through practices of representation'. (Nespor 1994, 131) Through these, teachers are able to bring the distant settings of the occupation to the central position of students in FE. An example offered by Nespor is the experience of Berkeley physicists, who he argues, are closer in space-time to colleagues in Europe, than to migrant workers in the next county, and managers in New York closer to their counterparts in Tokyo, than the poor of the South Bronx. Through action, we can interact with, '... things in the immediate environment and with people and things spatially and temporally removed from us'. Here, we can identify the same process at work for teachers, but rather than academic disciplines, what is being transported across time and space by the use of inscription devices, is occupational expertise.

This discussion sheds light on some of the characteristics of vocational knowledge and illuminates that codified, propositional curricula knowledge does not provide a sufficiently full experience for vocational students. Whilst codified knowledge is instrumental and fundamental to courses taught in FE colleges, it has limitations for the organisation of formal VET. Teachers, as evidenced through their CPD appear to recognise the limitations and supplement and enhance the provision by transporting current workplace knowledge into classrooms. This is of little surprise for two reasons. Firstly, due to the tacit and temporal nature of vocational knowledge. Secondly, because of the hollowing out over the past 30 years of VET, which now, according to Bathmaker (2013) is more often focussed on employability skills, rather than on vocational knowledge.

In conclusion, the concept 'knowledge in motion' coupled with workplace theories may offer a useful conceptual marriage for exploring the nature of vocational knowledge as taught to FE students following craft vocational and occupational courses. It suggests that vocational knowledge, rather than be seen as a dichotomy is perhaps more accurately viewed as being distributed and networked. It has made visible some of the ways teachers are able, through CPD activity, to transport it via networks and inscription devices from occupations to classrooms. These two conceptualisations begin to offer explanations as to the ways in which vocational curricula of codified and propositional knowledge fail to offer a sufficiently full learning experience for students. The research reported on here requires further work to identify more fully the paths that vocational teachers forge between classrooms and workplaces for their students. There is also more work to be done concerning how vocational teachers can be supported in pursuing effective CPD opportunities and indeed in what makes for effective CPD. 


\section{Notes}

1. A biennial international vocational skills completion for young people from 75 countries and regions.

2. A traditional English chair, dating from around the sixteenth century. The specific design includes a solid wooden seat with the back and arms made from steam bent spindles.

\section{Disclosure statement}

No potential conflict of interest was reported by the author.

\section{References}

Allix, N. M. 2011. “Knowledge and Workplace Learning." In The SAGE Handbook of Workplace Learning, edited by M. Malloch, L. Cairns, K. Evans, and B. N. O'Connor, 132-148. London: Sage.

Avis, J. 2012. "Global Reconstructions of Vocational Education and Training." Globalisation, Societies and Education 10 (1): 1-11.

Avis, J., R. Canning, R. Fisher, B. Morgan-Klein, and R. Simmons. 2012. "State Intervention and Teacher Education for Vocational Educators in England and Scotland." Educational Research 54 (2): 187-197.

Baiocchi, G., D. Graizbord, and M. Rodríguez-Muñiz. 2013. “Actor-network Theory and the Ethnographic Imagination: An Exercise in Translation." Qualitative Sociology 36 (4): 323-341.

Bathmaker, A. M. 2013. “Defining 'Knowledge' in Vocational Education Qualifications in England: An Analysis of Key Stakeholders and Their Constructions of Knowledge, Purposes and Content." Journal of Vocational Education \& Training 65 (1): 87-107.

Bound, H. 2011. "Vocational Education and Training Teacher Professional Development: Tensions and Context." Studies in Continuing Education 33 (2): 107-119.

Butcher, J. 2003. "'Sink or Swim': Learning to Teach Post-16 on an 11-18 Postgraduate Certificate in Education." Teacher Development 7 (1): 31-58.

Callon, M. 1986. "Some Elements of a Sociology of Translation: Domestication of the Scallops and the Fishermen of St Brieuc Bay." In Power, Action and Belief: A New Sociology of Knowledge, edited by J. Law, 196-233. London: Routledge.

Canning, R. 2008. "Reflecting on the Reflective Practitioner: Muddled Thinking and Poor Educational Practices". Paper presented at UCET conference, Birmingham, November 7-8.

CAVTL. 2013. It's about Work ... Excellent Adult Vocational Teaching and Learning. Coventry: Learning and Skills Improvement Services.

Ceulemans, C., M. Simons, and E. Struyf. 2012.“'Professional Standards for Teachers: How Do They'Work'? An Experiment in Tracing Standardisation in-the-Making in Teacher Education." Pedagogy, Culture \& Society 20 (1): 29-47.

Christiansen, J. K., and C. J. Varnes. 2007. "Making Decisions on Innovation: Meetings or Networks?" Creativity and Innovation Management 16 (3): 282-298.

Cordella, A., and Shaikh, M. (2006). From Epistemology to Ontology: Challenging the Constructed 'truth' of ANT. Working paper. London: Department of Information Systems, London School of Economics and Political Science.

Eraut, M. 2000. "Non-formal Learning and Tacit Knowledge in Professional Work." British Journal of Educational Psychology 70 (1): 113-136.

Eraut, M. 2004. "Transfer of Knowledge between Education and Workplace Settings." In Workplace Learning in Context, edited by H. Rainbird, A. Fuller, and A. Munro, 201-221. London: Routledge.

ETF. 2014. Professional Standards for Teachers and Trainers in Education and Training - England. London: Education and Training Foundation.

Evans, K., D. Guile, J. Harris, and H. Allan. 2010. "Putting Knowledge to Work: A New Approach." Nurse Education Today 30 (3): 245-251.

Fenwick, T., and R. Edwards. 2011. "Considering Materiality in Educational Policy: Messy Objects and Multiple Reals." Educational Theory 61 (6): 709-726. 
Fenwick, T., and R. Edwards. 2013.“Performative Ontologies: Sociomaterial Approaches to Researching Adult Education and Lifelong Learning." European Journal for Research on the Education and Learning of Adults 4 (1): 49-63.

Fenwick, T., M. Nerland, and K. Jensen. 2012.“'Sociomaterial Approaches to Conceptualising Professional Learning and Practice." Journal of Education and Work 25 (1): 1-13.

Fox, S. 2000. "Communities of Practice, Foucault and Actor-network Theory." Journal of Management Studies 37 (6): 853-868.

Fuller, A., D. N. Ashton, A. Felstead, L. Unwin, S. Walters, and M. Quinn. 2003. The Impact of Informal Learning at Work on Business Productivity. London: Department for Trade and Industry.

Gamble, J. 2006. "Theory and Practice in the Vocational Curriculum." In Knowledge, Curriculum and Qualifications for South African Further Education, edited by M. Young and J. Gamble, 87-103. Cape Town: HSRC Press.

Gholamreza, E., and M. R. Wolff. 2009. “Policy as Boundary Object: A New Way to Look at Educational Policy Design and Implementation." Vocations and Learning 2 (1): 19-35.

Gruber, E., I. Mande, and T. Oberholzner. 2008. "Modernising Vocational Education and Training." Fourth Report on Vocational Training Research in Europe. Background Report. 1:69-69.

Guile, D. 2010. The Learning Challenge of the Knowledge Economy. Rotterdam: Sense.

Guile, D. 2011. "Apprenticeship as a Model of Vocational 'Formation' and 'Reformation': The Use of Foundation Degrees in the Aircraft Engineering Industry." Journal of Vocational Education \& Training 63 (3): 451-464.

Hamilton, M. 2011. “Unruly Practices: What a Sociology of Translations Can Offer to Educational Policy Analysis." Educational Philosophy and Theory 43 (s1): 55-75.

Harris-Hart, C. 2009. "Performing Curriculum: Exploring the Role of Teachers and Teacher Educators." Curriculum Inquiry 39 (1): 111-123.

Harvey, D. 1989. The Condition of Postmodernity. Oxford: Basil Blackwell.

Hildreth, P. M., and C. Kimble. 2002. The Duality of Knowledge. Information Research 8 (1): 1-18.

Hordern, J. 2014. "How is Vocational Knowledge Recontextualised?" Journal of Vocational Education \& Training 66 (1): 22-38.

Keep, E., and S. James. 2011. "Employer Demand for Apprenticeships." In Rethinking Apprenticeships, edited by T. Dolphin and T. Lanning, 55-65, London: Institute for Public Policy Research.

Kotzee, B. 2012." Private Practice: Exploring the Missing Social Dimension in 'Reflective Practice.'” Studies in Continuing Education 34 (1): 5-16.

Latour, B. 1987. Science in Action: How to Follow Scientists and Engineers through Society. Cambridge, MA: Harvard University Press.

Latour, B. 1996. “On Actor-network Theory: A Few Clarifications plus More than a Few Complications." Soziale Welt 47 (4): 369-381.

Latour, B. 2007. Reassembling the Social: An Introduction to actor-network-theory. Oxford: Oxford University Press.

Lave, J., and E. Wenger. 1991. Situated Learning. Cambridge: Cambridge University Press.

Law, J., and J. Hassard, eds. 1999. Actor Network Theory and After. Oxford: Blackwell.

Lingfield, R. B. 2012. Proessionalism in Further Education. Final Report of the Independent Review Panel. London: Department for Business Innovation and Skills.

Livingstone, D. W., and Guile, D. 2012. "General Introduction." In The Knowledge Economy and Lifelong Learning, edited by D. W. Livingstone and D. Guile, xv-xxi. Rotterdam: Sense.

Lloyd, C., and J. Payne. 2012. "Raising the Quality of Vocational Teachers: Continuing Professional Development in England, Wales and Norway." Research Papers in Education 27 (1): 1-18.

Malcolm, J., and M. Zukas. 2009. "Making a Mess of Academic Work: Experience, Purpose and Identity." Teaching in Higher Education 14 (5): 495-506.

McArdle, K., and A. Ackland. 2007. "The Demands of the Double Shift: Communities of Practice in Continuing Professional Development." Journal of Vocational Education and Training 59 (1): 107-120.

Mulcahy, D. 2011. "Assembling the'Accomplished'Teacher:The Performativity and Politics of Professional Teaching Standards." Educational Philosophy and Theory 43 (s1): 94-113.

Muller, J. 2009. "Forms of Knowledge and Curriculum Coherence." Journal of Education and Work 22 (3): 205-226. 
Munro, R. (2009). "Actor-network Theory." In The SAGE Handbook of Power, edited by S. R. Clegg and M. Haugaard, 125-139, London: Sage.

Mützel, S. 2009. “Networks as Culturally Constituted Processes: A Comparison of Relational Sociology and Actor-network Theory." Current Sociology 57 (6): 871-887.

Nespor, J. 1994. Knowledge in Motion: Space, Time and Curriculum in Undergraduate Physics and Management. Knowledge, Identity and School Life Series: 2. Bristol: Falmer Press.

Polanyi, M. 1967. The Tacit Dimension: New York: Doubleday.

Schön, D. A. 1991. The Reflective Practitioner: How Professionals Think in Action. Aldershot: Avebury.

Star, S. 1990. "The Structure of III-structured Solutions: Boundary Objects and Heterogeneous Distributed Problem Solving." In Distributed Artificial Intelligence, edited by L. Gasser and M. N. Huhns, 37-54. London: Pitman.

Statutory Instrument. 2012. The Further Education Teachers' Continuing Professional Development and Registration (England) (Revocation) Regulations, 2165 (pp. 2). London: HMSO.

Unwin, L. 2004. "Twenty-first Century Vocational Education in the United Kingdom: What Would Dickens Think?" Pedagogy Culture and Society 12 (2): 175-200.

Wheelahan, L. 2007. "How Competency-based Training Locks the Working Class out of Powerful Knowledge: A Modified Bernsteinian Analysis." British Journal of Sociology of Education 28 (5): 637-651.

Wolf, A. 2011. Review of Vocational Education. London: Department of Education.

Young, M. F. D. 2008. Bringing Knowledge Back in: From Social Constructivitsm to Social Realism in the Sociology of Education. Abingdon: Routledge.

Zollo, M., and S. G. Winter. 2002. "Deliberate Learning and the Evolution of Dynamic Capabilities." Organization Science 13 (3): 339-351. 